MaPan : Jurnal Matematika dan Pembelajaran

p-ISSN: 2354-6883 ; e-ISSN: 2581-172X

Volume 6, No 2, December 2018 (199-206)

DOI: https://doi.org/10.24252/mapan.2018v6n6

\title{
MATHEMATICAL LEARNING OUTCOME DIFFERENCES THROUGH THE IMPLEMENTATION OF COOPERATIVE LEARNING MODEL OF THINK PAIR SHARE TYPE, TWO STAY TWO STRAY TYPE, AND NUMBER HEAD TOGETHER TYPE
}

\author{
Fitriani Nur1), Nur Khalisah Latuconsina'2), Andi Ika Prasasti Abrar3), \\ Thamrin Tayeb ${ }^{4)}$, Ira Syamsuarni ${ }^{5}$ ) \\ 1,2,3,4,5Fakultas Tarbiyah dan Keguruan UIN Alauddin Makassar \\ 1,2,3,4,5Kampus II: Jalan H. M. Yasin Limpo Nomor 36 Samata-Gowa \\ E-mail: fitrianinur@uin-alauddin.ac.id ${ }^{1}$, nurkhalisaltc99@gmail.com ${ }^{2}$, \\ andi.ika.prasasti@uin-alauddin.ac.id ${ }^{3}$ ), thamrin.tayeb@uin-alauddin.ac.id ${ }^{4}$, \\ irasyamsuarni@gmail.com ${ }^{5)}$
}

Submitted: 24-09-2018, Revised: 27-12-2018, Accepted: 27-12-2018

\begin{abstract}
:
The study aims to find out the students' mathematical learning outcome differences through the implementation of cooperative learning model of Think Pair Share (TPS) type, Two Stay Two Stray (TSTS) type, and Numbered Heads Together (NHT) type. The study used quasi-experimental research design. The population of this study was all the second grade students of SMPN 1 Pallangga that consisted of 11 classes with the total number of 343 students. The sample was determined by using purposive sampling technique. The data analyses techniques used were descriptive and inferential statistics by using F one-way Anova test and follow-up testing by using Scheffe test. Based on the statistics analysis, it was found that there were the students' mathematical learning outcome differences through the implementation of Think Pair Share (TPS) type, and Two Stay Two Stray (TSTS) type at the second grade of SMPN 1 Pallangga. Based on the mean scores, the highest score of the students' learning outcomes was the experimental class implemented learning model of TPS type.
\end{abstract}

Keywords: Learning Outcome, Think Pair Share (TPS), Two Stay Two Stray (TSTS), Numbered Heads Together (NHT)

\section{PERBEDAAN HASIL BELAJAR MATEMATIKA MELALUI PENERAPAN MODEL PEMBELAJARAN KOOPERATIF TIPE THINK PAIR SHARE, TWO STAY TWO STRAY, DAN NUMBERED HEADS TOGETHER}

\begin{abstract}
Abstrak:
Penelitian ini bertujuan untuk mengetahui perbedaan hasil belajar matematika siswa melalui penerapan model pembelajaran kooperatif tipe Think Pair Share (TPS), Two Stay Two Stray (TSTS), dan Numbered Heads Together (NHT). Jenis penelitian ini menggunakan quasi experiment. Populasi pada penelitian ini adalah seluruh peserta didik kelas VII SMPN 1 Pallangga yang terdiri dari 11 kelas, yang berjumlahkan 343 siswa. Penentuan sampel dengan menggunakan teknik
\end{abstract}


purposive sampling. Teknik analisis data yang digunakan adalah statistik deskriptif dan analisis statistik inferensial dengan menggunakan uji $\mathrm{F}$ one-way Anava dan uji lanjut dengan menggunakan uji Scheffe. Berdasarkan analisis statistika menunjukkan bahwa terdapat perbedaan hasil belajar matemaika siswa melalui penerapan model pembelajaran kooperatif tipe Think Pair Share (TPS), Two Stay Two Stray (TSTS), dan Numbered Heads Together (NHT) pada kelas VII SMPN 1 Pallangga. Berdasarkan nilai rerata, hasil belajar matematika siswa yang tertinggi adalah kelas eksperimen yang menerapkan model pembelajaran tipe TPS.

Kata Kunci: Hasil Belajar, Think Pair Share (TPS), Two Stay Two Stray (TSTS), Numbered Heads Together (NHT)

How to Cite: Nur, F., Latuconsina, N. K., Abrar, A. I. P., Tayeb, T., \& Syamsuarni, I. (2018). Mathematical Learning Outcome Differences Through the Implementation of Cooperative Learning Model of Think Pair Share Type, Two Stay Two Stray Type, and Number Head Together Type. MaPan : Jurnal Matematika dan Pembelajaran, 6(2), 199-206.

$\mathrm{E}$ ducation is an activity carried out based on the plan and the design that we have made so that the learning and teaching process between students and teacher in the classroom is created by the expectation that the students ability can be improved more. Human resource is such a big challenge for national education system to provide human resources with high cognitive ability and sufficient ability on technology based on the market needs. One of the top problems that always become the topic of discussion is in mathematics. Mathematical problems are caused by the lack of concept understanding. The problem must be considered by every teacher in order to create the learning activities that actively involve every student in the learning processes. The method can be used by a teacher to realize enjoyable learning in the learning process is by implementing a learning model (Kusumaningrum, Budiyono, \& Subanti, 2015: 706).

Based on the observation and interview results conducted by the writers in SMPN 1 Palangga, it was found that in math learning processes, the teacher still implemented conventional learning model, in which the teacher only explained the material conceptually by giving exercises and tasks. It made the students less active in the learning processes, while the interview result stated that the students' math learning outcomes were above the standard of 50\% from the KKM value of 75. Therefore, to increase the students' learning outcomes, there is a solution given by considering the enjoyable learning condition that can activate the student namely by implementing the cooperative learning of Think Pair Share (TPS), Two Stay Two Stray (TSTS), and Numbered Heads Together (NHT) types. By considering the previous researches conducted by Kholilah Amriani Harahap and Edy Suryab, it showed that the students who used cooperative learning model of TSTS type became increase from low learning outcomes before implementing the 
model to high learning outcomes after implementing it (Harahap \& Suryab, 2017: 162). The research conducted by Yusrina Santri Nasutiona and Edy Suryab showed that by implementing a model of cooperative learning with NHT type in a learning process, it could increase the students' learning outcomes (Nasution \& Surya, 2017: 121). The research conducted by Zainuddin et al, showed that the cooperative learning model of TSTS type gave math learning outcomes better than cooperative learning model of NHT type and direct learning model, while the cooperative learning model of NHT model gave math learning outcomes similar to the direct learning model (Zainuddin, Budiyono, \& Sujadi, 2014: 129).

Math learning outcomes are the changes in attitudes and behavior from the abilities acquired by the students of the math understanding itself based on the educational level that the students have. Mathematics is a subject that has clear techniques consist of facts, complicated and sophisticated concepts that are more appropriate for academic research (Ernest, 2014: 154). It means that math learning is not only learning about the concept but also related to the methods or strategies in solving a problem.

The cooperative learning model of TPS type was firstly introduced by Frank Lyman in 1981 (Aqib, 2013: 24). The model is a learning model in which the students are given time to think individually and work together in groups and in pairs. This model is more simple because it does not take long time for group division (Shoimin, 2016: 208). TSTS is a cooperative type in which the students not only discuss with their own group but also discuss with other groups by sending two students as the guests of other groups while two remaining students are obliged to receive the guests from other groups (Rozaiah, Wati, \& Mastuang, 2017: 55), whereas, NHT type is a cooperative learning model developed by Spenser Kagan. In this model, the students will be given different numbers in one group and every student has his/her own task in the group so that the students can concentrate more in the learning process (Shoimin, 2016: 107). Based on those point of views, the writers conclude that the cooperative learning model referred to this study is the learning that divides the students into some groups and every group member has his/ her own role or task, while the cooperative learning of TPS, TSTS, NHT types are very good to be implemented in a learning process in order to increase the students' learning outcomes. Every role or task given to the students is expected to become one of causes that makes the students will actively participate in the learning process. In addition, every group member not only interacts with his/her own group, but also interacts with other groups so that the idea and the results are not only fixed on one group.

\section{METHOD}

This study used quasi-experimental research design with quantitative approach and used nonequivalent control group design, as follows: 
Table 1. Nonequivalent Control Group Design

\begin{tabular}{cccc}
\hline Group & Pretest & Treatment & Posttest \\
\hline $\begin{array}{c}\text { Experiment } \\
\text { (Cooperative Learning Model of TPS } \\
\begin{array}{c}\text { Type) } \\
\text { Experiment } 2\end{array}\end{array}$ & $\mathrm{O}_{1}$ & $\mathrm{X}$ & $\mathrm{O}_{2}$ \\
$\begin{array}{c}\text { Type) } \\
\text { (Cooperative Learning Model of TSTS } \\
\begin{array}{c}\text { Experiment } \\
\text { (C) }\end{array}\end{array}$ & $\mathrm{O}_{3}$ & $\mathrm{X}$ & $\mathrm{O}_{4}$ \\
$\begin{array}{c}\text { (Cooperativing Model of NHT } \\
\text { Type) }\end{array}$ & $\mathrm{O}_{5}$ & $\mathrm{X}$ & $\mathrm{O}_{6}$ \\
\hline
\end{tabular}

Description:

$\mathrm{X}=$ Treatment

$\mathrm{O}_{1}=$ The score of experimental group $\mathrm{p}_{1}$ before implementing cooperative learning model of TPS type (the pretest score of experimental group $p_{1}$ )

$\mathrm{O}_{2}=$ The score of experimental group ${ }_{1}$ after implementing cooperative learning model of TPS type (the posttest score of experimental group p $_{1}$

$\mathrm{O}_{3}=$ The score of experimental group 2 before implementing cooperative learning model of TSTS type (the pretest score of experimental group 2 )

$\mathrm{O}_{4}=$ The score of experimental group 2 after implementing cooperative learning model of TSTS type (the posttest score of experimental group 2 )

$\mathrm{O}_{5}=$ The score of experimental group 3 before implementing cooperative learning model of NHT type (the pretest score of experimental group ${ }_{3}$ )

$\mathrm{O}_{6}=$ The score of experimental group 3 after implementing cooperative learning model of NHT type (the posttest score of experimental group g) $_{3}$

The study was conducted in SMPN 1 Pallangga of the second grade class (class VII) with the total number of 343 students. The study used purposive sampling technique in determining the sample of the study. The samples selected were class $\mathrm{VII}_{11}$, class $\mathrm{VII}_{10}$, and class $\mathrm{VII}_{8}$ which totaled 96 students as experimental classes of each. The data collection used written test and observation sheet. The test given consisted of pretest and posttest. Furthermore, from the pretest and posttest, it was obtained the description data of the students' learning outcomes, whereas, through the observation sheet, it was obtained the data about the implementation of the lesson plan (RPP) and the students' activeness in the learning process. The research instruments used were the test that consisted of essay tests and observation sheet about the lesson plan implementation and students' activeness.

The data analysis techniques used were descriptive statistic technique and inferential statistic technique by using F one-way anova test and follow-up testing by using Scheffe test, but the writers used prerequisite test first that consisted of normality and homogeneity tests. 


\section{FINDINGS AND DICUSSION}

The following is the descriptive analysis table of the students' math learning outcomes by implementing the cooperative learning model of TPS, TSTS, and NHT types.

Table 2. Pretest and Posttest Description of Experimental Class 1 , Experimental Class2, and Experimental Class 3

\begin{tabular}{ccccccc}
\hline Statistic & \multicolumn{2}{c}{$\begin{array}{c}\text { Statistic Score } \\
\text { Experimental } \\
\text { Class }^{2}\end{array}$} & \multicolumn{2}{c}{$\begin{array}{c}\text { Statistic Score } \\
\text { Experimental } \\
\text { Class }\end{array}$} & $\begin{array}{c}\text { Statistic Score } \\
\text { Experimental } \\
\text { Class }\end{array}$ \\
\cline { 2 - 7 } & Pretest & Posttest & Pretest & Posttest & Pretest & Posttest \\
\hline Number of & 32 & 32 & 32 & 32 & 32 & 32 \\
Sample & & & & & & \\
Lowest Score & 35 & 55 & 30 & 65 & 20 & 55 \\
Highest Score & 60 & 100 & 60 & 100 & 55 & 95 \\
Mean Score & 47.62 & 83.75 & 46.68 & 83.63 & 39.19 & 75.06 \\
Standard & 8.54 & 12.54 & 8.42 & 10.72 & 9.7 & 12.31 \\
Deviation & & & & & & \\
\hline
\end{tabular}

The table shows that every student has increasing learning outcome mean scores after being given posttest in which experimental class ${ }_{1}$ has increased as many as $36.13 \%$ from the pretest mean score of 47.62 becomes 83.75 on the posttest mean score. The experimental class 2 has increased as many as $36.95 \%$ from the pretest mean score of 46.68 becomes 83.63 on the posttest mean score, while the experimental class 3 has increased as many as $35.87 \%$ from the pretest mean score of 39.19 becomes 75.06 on the posttest mean score. If the students' learning outcomes are grouped into a categorization, it is known that after implementing the cooperative learning model of TPS type, the students' learning outcomes increase in the medium category, the students' learning outcomes increase in the high category after implementing the cooperative learning model of TSTS type, and the students' learning outcomes increase in high category after implementing the cooperative learning model of NHT type. Therefore, the students' learning outcomes become increase after implementing the cooperative learning model of TPS type, TSTS type, and NHT type.

The following is the analysis result of inferential statistic by using F oneway Anova test on the second grade students of SMPN 1 Pallangga, as follows:

Table 3. F (Anova) Test Result of the Students' Math Learning Outcomes 


\begin{tabular}{lccccc}
\hline & $\begin{array}{l}\text { Sum of } \\
\text { Squares }\end{array}$ & Df & $\begin{array}{c}\text { Mean } \\
\text { Square }\end{array}$ & F & Sig. \\
\hline $\begin{array}{l}\text { Between } \\
\begin{array}{l}\text { Groups } \\
\text { Within }\end{array}\end{array}$ & 1438.188 & 2 & 719.094 & 5.256 & .007 \\
$\begin{array}{l}\text { Groups } \\
\text { Total }\end{array}$ & 12723.812 & 93 & 136.815 & & \\
\hline
\end{tabular}

Based on the data analysis results, it is obtained the sig value $=0.007$ which means that before and after implementing the learning model, there is a difference among the students implementing cooperative learning model of TPS, TSTS, and NHT types at the second grade of SMPN 1 Pallangga.

The following is the table of follow-up testing results by using Scheffe test. This testing is conducted in order to know the groups' significant differences.

Table 4. The Results of Scheffe Test

\begin{tabular}{|c|c|c|c|c|c|c|}
\hline \multicolumn{7}{|c|}{ Multiple Comparisons } \\
\hline \multicolumn{7}{|c|}{ Dependent Variable: POSTTEST RESULTS } \\
\hline \multicolumn{7}{|c|}{ Scheffe } \\
\hline \multirow{2}{*}{ (I) CLASS } & \multirow{2}{*}{ (J) CLASS } & \multirow{2}{*}{$\begin{array}{c}\text { Mean } \\
\text { Difference } \\
\text { (I-J) }\end{array}$} & \multirow{2}{*}{$\begin{array}{l}\text { Std. } \\
\text { Error }\end{array}$} & \multirow[b]{2}{*}{ Sig. } & \multicolumn{2}{|c|}{$\begin{array}{c}\text { 95\% Confidence } \\
\text { Interval }\end{array}$} \\
\hline & & & & & $\begin{array}{l}\text { Lower } \\
\text { Bound }\end{array}$ & $\begin{array}{l}\text { Upper } \\
\text { Bound }\end{array}$ \\
\hline \multirow{3}{*}{$\begin{array}{l}\text { EXPERIMENT } \\
\text { AL CLASS } 1\end{array}$} & EXPERIME & .406 & 2.924 & .990 & -6.87 & 7.68 \\
\hline & $\begin{array}{l}\text { NTAL } \\
\text { CLASS } 2\end{array}$ & & & & & \\
\hline & $\begin{array}{l}\text { EXPERIME } \\
\text { NTAL } \\
\text { CLASS } 3\end{array}$ & $8.406^{*}$ & 2.924 & .019 & 1.13 & 15.68 \\
\hline \multirow{3}{*}{$\begin{array}{l}\text { EXPERIMENT } \\
\text { AL CLASS } 2\end{array}$} & EXPERIME & -.406 & 2.924 & .990 & -7.68 & 6.87 \\
\hline & $\begin{array}{l}\text { NTAL } \\
\text { CLASS } 1\end{array}$ & & & & & \\
\hline & $\begin{array}{l}\text { EXPERIME } \\
\text { NTAL } \\
\text { CLASS } 3\end{array}$ & $8.000^{*}$ & 2.924 & .027 & .73 & 15.27 \\
\hline \multirow[t]{2}{*}{$\begin{array}{l}\text { EXPERIMENT } \\
\text { AL CLASS } 3\end{array}$} & $\begin{array}{l}\text { EXPERIME } \\
\text { NTAL } \\
\text { CLASS } 1\end{array}$ & $-8.406^{*}$ & 2.924 & .019 & -15.68 & -1.13 \\
\hline & $\begin{array}{l}\text { EXPERIME } \\
\text { NTAL } \\
\text { CLASS } 2\end{array}$ & $-8.000^{*}$ & 2.924 & .027 & -15.27 & -.73 \\
\hline
\end{tabular}

*. The mean difference is significant at the 0.05 level.

Based on the follow-up testing, it is found that: (1) the learning outcomes through the implementation of TPS learning model does not have significant difference with the learning outcomes through the implementation of TSTS learning model by the mean difference only 0.406, (2) the learning outcome through the implementation TPS learning model is significantly different with the 
learning outcomes through the implementation of NHT learning model by the mean difference as many as 8.406, and (3) the learning outcomes through the implementation of TSTS learning model is significantly different with the learning outcomes through the implementation of NHT learning model by the mean difference as many as 8.000 .

The results of the follow-up testing are in line with the research findings that state that there is no significant difference of the ability between the cooperation with cooperative learning model of TPS type and TSTS type, and the cooperative learning model of TSTS type is better than the cooperative learning model of NHT type (Hasanah, Idrus, \& Mertha, 2015: 220; Riska, Safei, \& Afiif, 2015: 71).

\section{CONCLUSION}

Based on the findings, the writers can conclude that there is a difference of the students' math learning outcome through the implementation of cooperative learning model of Think Pair Share (TPS) type, Two Stay Two Stray (TSTS) type, and Numbered Heads Together (NHT) type at the second grade of Junior High School 1 (SMPN 1) Pallangga. Based on the mean score, the highest score of the students' math learning is the experimental class that implemented the learning model of TPS type.

\section{REFERENCES}

Aqib, Z. (2013). Model-model, media, dan strategi pembelajaran. Bandung: Yrama Widya.

Ernest, P. (2014). The philosophy of mathematics education. British Library Cataloguing in Publication Data.

Harahap, K. A., \& Suryab, E. (2017). Application of cooperative learning model with type of two stay two stray to improve results of mathematics teaching. International Journal of Sciences: Basic and Applied Research (IJSBAR), 33(2), 156165.

Retrieved

from

http:/ / gssrr.org/index.php?journal=JournalOfBasicAndApplied\&page=arti cle\&op=view \&path $\% 5 \mathrm{~B} \% 5 \mathrm{D}=7370 \&$ path $\% 5 \mathrm{~B} \% 5 \mathrm{D}=3456$

Hasanah, M., Idrus, A. Al, \& Mertha, I. G. (2015). Perbedaan hasil belajar ipa biologi menggunakan model pembelajaran kooperatif tipe numbered heads together (NHT) dengan think pair share (TPS) pada siswa kelas VIII SMPN 13 Mataram Tahun Ajaran 2015/2016. Jurnal Tadris IPA Biologi FITK IAIN Mataram, 7(2), 211-225. Retrieved from https://anzdoc.com/abstrak-katakunci-pembelajaran-kooperatif-think-pair-share-.html

Kusumaningrum, R., Budiyono, B., \& Subanti, S. (2015). Eksperimentasi model pembelajaran kooperatif tipe two stay two stray (TSTS), numbered heads together (NHT), dan think pair share (TPS) pada materi lingkaran ditinjau 
dari kreativitas belajar matematika siswa SMP Negeri di Kabupaten Sukoharjo. Jurnal Elektronik Pembelajaran Matematika, 3(7), 705-716. Retrieved from

http://jurnal.fkip.uns.ac.id/index.php/s2math/article/view/6488/4428

Nasution, Y. S., \& Surya, E. (2017). Application of TPS type cooperative learning in improving students' mathematics learning outcomes. International Journal of Sciences: Basic and Applied Research (IJSBAR), 34(1), 116-125. Retrieved from http:/ / gssrr.org/index.php?journal=JournalOfBasicAndApplied\&page=arti cle\&op=view \&path $\% 5 B \% 5 D=7564 \&$ path $\% 5 B \% 5 D=3514$

Riska, Safei, \& Afiif, A. (2015). Perbandingan kemampuan kerjasama dan berpikir kreatif peserta didik melalui penerapan model kooperatif tipe think pair share dan two stay two stray. Jurnal Ilmiah Pendidikan Fisika, 3(1), 68-71. Retrieved from http://journal.uinalauddin.ac.id/index.php/PendidikanFisika/article/view/4102/3792

Rozaiah, N., Wati, M., \& Mastuang. (2017). Perbedaan hasil belajar siswa menggunakan model pembelajaran kooperatif tipe think pair share (TPS) dengan tipe two stay two stray (TSTS) pada kelas XI IPA SMA Negeri 4 Banjarmasin. Jurnal Ilmiah Pendidikan Fisika, 1(1), 50-63. Retrieved from https://anzdoc.com/nazua-rozaiah-mustika-wati-mastuang-prodipendidikan-fisika-.html

Shoimin, A. (2016). 68 Model pembelajaran inovatif. Yogyakarta: Ar-Ruzz Media.

Zainuddin, Budiyono, \& Sujadi, I. (2014). Eksperimentasi model pembelajaran kooperatif tipe two stay two stray dan numbered heads together pada materi pokok fungsi ditinjau dari kecerdasan interpersonal siswa kelas VIII SMP Negeri Se-Kota Surakarta. Jurnal Elektronik Pembelajaran Matematika, 2(2), 121130. http://jurnal.fkip.uns.ac.id/index.php/s2math/article/view/3884/2750 